\title{
USING SIMULATION TO IMPROVE HOSPITAL RESOURCE MANAGEMENT
}

\begin{abstract}
Emergency Department is a primary health care unit of hospitals, and usually one of the main entrances to the hospital and a key part of the health care system. Increasing demand for emergency care, overcrowding and limited resources are phenomena that cause much delay for patients in ED. In other hand, because the philosophy of creating ED, patient shouldn't stay too long in ED. Long waiting time led to congestion and disturbance in ED process. This study seeks to reduce patient's waiting time and length of stay in ED. By noticing simulation result increasing 3 beds and 1 GP that cause $17.4 \%$ improvement in bed utilization and $35.1 \%$ in GP utilization, and improve average waiting time for visiting GP and average waiting time for hospitalization $82 \%$ and $86 \%$ respectively and $8 \%$ decrease length of stay is the best scenario.
\end{abstract}

Key words: emergency department, length of stay, resource allocation, simulation

\section{Introduction}

Healthcare system is one of services with rapid growth in both developed and developing countries. The first aim of this system is to improve the quality of services and health of people in their daily life. Patients are the main focus of health care system can they be considered as customers with different expectations in this complex systems (Faezipour \& Ferreira, 2013). In recent years, changing pattern of disease, progression in medical knowledge and technology, public awareness of modern medical facilities along with increasing the elderly population cause more demand for medical services. This increased demand has led to more pressure on the health care budget. So, trying to prevent the rising

Khodakaram Salimifard, Persian Gulf University, Iran, e-mail: salimifar@pgu.ac.ir

** Dariuosh Mohammadi Zanjirani, Esfahan University, Iran, e-mail: dar_mohamadi@ yahoo.com

*** Leyla Keshtkar, Persian Gulf University, Iran, e-mail: lkeshtkar@mehr.pgu.ac.ir 
costs of healthcare by better using of scarce resources is a major challenge for manager (Ferreira, Gomes, \& Yasin, 2011).

Emergency Department is a primary health care unit in hospital and it is usually one of the main entrances to the hospital system. Due to the sensitivity and importance of its work it has special attention among other parts of hospital such that how to provide services in this segment can represent the overall status of hospital services. Properly and correct and timely function in ED can save many lives of patients. This requires good understanding and scrutiny of the current situation in this sector. In many cases, lack of resources such as beds, GPs and nurses in the care process prevent timely and suitable services and reducing health care quality and increase potential medical errors, long waiting times and patient's length of stay that all of them have unpleasant consequences for patients and also higher costs and unintended consequences for many service providers. Hence, achieving a better balance between supply and demand can improve service quality and bring satisfaction for patients in the emergency department $(\mathrm{Xu}$, Wong, \& Chin, 2013). In past years the result show that conventional models for higher quality of service and solving these problems in healthcare system have been failed. Thus, authorities are seeking to creative and scientific methods (Ferreira, Gomes, \& Yasin, 2011). In this regard, many organizations in attempt to overcome this varied challenge are using simulation as an aid for planning and allocation of resources (Alkaabi, El Halim, \& Mahmoud, 2006).

\section{Literature review}

Resource allocation is one the oldest areas of operations research in healthcare (Brailsford \& Vissers, 2011). Because of the importance and specific conditions of healthcare there is a lot of effort for budgeting and resource allocation to maximize the use of scarce resources. For example, (Ahmad, Abdul Ghani, Abdulbasah Kamil, Mat Tahar, \& Howe Teo, 2012) in their paper present a computer simulation model to assess use of resource utilization in the emergency department of a public hospital in Malaysia. By using this model administrators can monitor the patient flow in ED and find possible areas for improvement and do the best resource allocation. (Weng, Cheng, Ting Kwong, Wang, \& Chang, 2011) state that the purpose of their research was to find an optimal allocation of resources in the emergency department through simulation. They use Simul8 and the result show that overall performance in ED can increase $8 \%$ by allocating new human resources. (Cochran \& Broyles, 2010) propose making strategic decisions for future capacity based on patient safety (rather than congestion measures) in their study. (Ng, et al., 2010) in their study compare priorities and the differences between resource utilization in four-level of Taiwan triage and five-level of Canadian triage and acuity scale among patients. The results of this 
study show that hospitalization rates, length of stay and medical resource consumption is different between the two systems, and Canada triage acts better in predicting patient acuity and resource utilization. (Berge Holm \& Dahl, 2010) notice to increase $45 \%$ in patient's volume and its significant impact on patient flow in the emergency department and highlight this question to hospital managers "What is the lowest number of additional resources that would be needed in the $\mathrm{ED}$, due to the patient volume increase, which would not compromise the patient flow?". They use discrete event simulation to answer this question. The results of this study show that increasing nurses from eight to nine and increased physician from eight to twelve is enough to meet the needs of the hospital's emergency department. (Ahmed \& Alkhamis, 2009) by using simulationoptimization present a decision support tool for performance in an emergency department of a public hospital in Kuwait. The main purpose of this study is to evaluate the effect of different levels of staffing in service efficiency. This technique uses for determining the optimum number of doctors, nurses and lab technicians that need to maximize patient throughout and reduce patient's waiting time in system with budget constraints. (Withanachchi, Uchida, Nanayakkara, Samaranayake, \& Okitsu, 2007) analyze the effect of resource allocation in public hospitals which are under the central health ministry. In this model it is supposed that hospital administrator and other agents looking for maximum quality (compared with profit). Mortality rate among patients was chosen as an indicator of quality and impact of resource allocation on this index are studied. Finding show that utilization of human resources due to insufficient funds (for example, medical equipment, etc.) is suboptimal and should be improved. (Khandekar, Mari, \& Wang, 2007) focused on ED by using simulation in order to reducing patient's waiting time and increasing throughout. The findings were considered to facilitate the design care processes of a new hospital

\section{Research methodology}

\subsection{System description}

The hospital emergency department is open 24 hours a day in three morning, afternoon and night shifts. Medical services per shift are provided by 2 GPs, 1 specialist and 8 nurses and on call specialists.

Patients arrive by an ambulance or with their feet. Then, based on Emergency Severity Index are classified into five levels in triage stage. After visiting doctor they go on other care steps such as examination, injection, ECG and etc. At the end patients will exit from ED to continue their care in other parts of hospital or go to home. 


\subsection{Key performance indicators selection}

After visiting and interviewing by ED manager three main key performance have identified that include resource utilization (\%), average patient's waiting time (Min) and average total patient's length of stay (Min) in ED.

\subsection{Data Collection}

Data were collected by going directly to ED and using triage database and also tracing patients in different time intervals. In some cases that direct and random sampling wasn't possible, ED s daily and monthly data was used. All distributions were validated by using Kolmogorov Smirnov goodness of fit test with a $5 \%$ significance level (Table1).

Table 1: Service time distributions at each stage of the process

\begin{tabular}{|c|c|c|c|c|c|}
\hline $\begin{array}{c}\text { Input } \\
\text { Parameter }\end{array}$ & $\begin{array}{c}\text { Mean time for } \\
\text { service }\end{array}$ & Variance & K-S Test & P-value & Distribution \\
\hline Triage & 1.23 & 0.42 & 1.2 & 0.08 & Weibull \\
\hline Reception & 1.64 & 0.99 & 0.97 & 0.30 & Possion \\
\hline Visit & 3.90 & 1.6 & 0.61 & 0.84 & Possion \\
\hline Injection & 4.40 & 1.65 & 0.63 & 0.80 & Normal \\
\hline Minor Surgery & 11.3 & 9.11 & 0.73 & 0.64 & Exponential \\
\hline
\end{tabular}

\subsection{Model validation}

The aim of verification is to ensure that the conceptual model is reflected accurately in the simulation model. Validating is overall process of comparing a model and its behavior to the real system (Sadjadi, Soltani, Izadkhah, Saberian, \& Darayi, 2011). At first the conceptual model had been confirmed and validated by ED senior managers and senior nursing staff. After running the simulation model since there is no significant difference between the real performances indicators compared with output of the model the validation is confirmed (Table3).

Table 2: Model validation

\begin{tabular}{|c|c|c|c|}
\hline $\begin{array}{c}\text { Difference } \\
(\mathbf{m i n})\end{array}$ & $\begin{array}{c}\text { Average simulation } \\
\text { output (min) }\end{array}$ & $\begin{array}{c}\text { Average real data } \\
(\mathbf{m i n})\end{array}$ & $\begin{array}{c}\text { Spend time in } \\
\text { each stage }\end{array}$ \\
\hline 0.3 & 0.91 & 1.21 & Triage \\
\hline 1.2 & 4.91 & 3.69 & GP \\
\hline 0.13 & 1.52 & 1.65 & Reception \\
\hline 1.1 & 5.62 & 4.5 & Injection \\
\hline 0.4 & 6.9 & 7.3 & ECG \\
\hline
\end{tabular}




\section{Scenario analyses and discussion}

Arena software is capable to give various outputs according to simulator purpose. As mentioned above, resource utilization, patient's length of stay, patient's waiting time are the most important key that we notice to ED simulation. For having sufficient accuracy in interpreting of simulation outputs, simulation has run in 10 replications that each replication consists of 365 days. The output shows the main resource utilization is in Beds, GPs and nurses that play important roles in patient's length of stay and waiting time (Table 3).

Table 3: Model validation

\begin{tabular}{|c|c|c|c|}
\hline \multicolumn{2}{|c|}{ Key performance } & Current system & Mean in 10 replications \\
\hline \multirow{3}{*}{ Resource utilization } & Bed & 14 & 0.86 \\
\cline { 2 - 4 } & GP & 2 & 0.74 \\
\cline { 2 - 4 } & Nurse & 3 & 0.52 \\
\hline
\end{tabular}

Lack of sickbeds in this ED is one of the main reasions for congestion and overcrowded that have direct effect on patient's length of stay and waiting time. By adding 1 bed, bed utilization rate 6\% is decreased. This rate can be reduced to $11 \%$ by adding two beds. In the next step, increasing beds and their impact on patient waiting times and total length of stay is examined (Table4).

Table 4: Relation of number of beds and average wanting time for taking bed and average length of stay for inpatient

\begin{tabular}{|c|c|c|c|c|}
\hline Bed & $\begin{array}{c}\text { Average length } \\
\text { of stay for } \\
\text { inpatient(Min) }\end{array}$ & $\begin{array}{c}\text { Improvement in } \\
\text { average wanting } \\
\text { time for taking } \\
\text { bed \% }\end{array}$ & $\begin{array}{c}\text { Average wanting } \\
\text { time for taking } \\
\text { bed(Min) }\end{array}$ & $\begin{array}{c}\text { Improvement in } \\
\text { average length of } \\
\text { stay for inpatient } \\
\%\end{array}$ \\
\hline 14 current system & 59.6 & - & 603.6 & - \\
\hline 15 & 31.63 & $46 \%+$ & 576.5 & $4.4 \%+$ \\
\hline 16 & 15.22 & $74 \%+$ & 564.2 & $6.5 \%+$ \\
\hline 17 & 8.35 & $85 \%+$ & 558.1 & $7.5 \%+$ \\
\hline
\end{tabular}

According to analyses by adding sickbeds from 14 to 15 beds, the average waiting times for admission from 59.6 Minutes is reduced to 31.63 minutes and also cause $4.4 \%$ improvement in the average length of stay. Adding two beds reduce waiting times form 31.63 minutes to 15.22 minutes and recovered $6.5 \%$ on average length of stay and adding three beds, reduced average waiting time for admission from 15.22 to the 8.35 minutes and improve $7.5 \%$ in average total length of stay for inpatients. 
Another major source in ED is nurse. In the current system, the utilization rate of 3 nurses for inpatient is 52 percent while by increasing 1 nurse and 2 nurses the rate can be 49 and 47 respectively. Thus increasing 2 nurses will improve 9.6\% in nurse utilization.

The analysis of results show although increaseing a nurse dosent have much impact on the average waiting time for taking bed but it will improve $0.58 \%$ in average average total length of stay for inpatients(Table5).

Table 5: Relation of number of nurse and average wanting time for taking bed and average length of stay for inpatient

\begin{tabular}{|c|c|c|c|c|}
\hline Nurse & $\begin{array}{c}\text { Average wanting } \\
\text { time for taking } \\
\text { bed (Min) }\end{array}$ & $\begin{array}{c}\text { Improvement in } \\
\text { average wanting } \\
\text { time for } \\
\text { taking bed \% }\end{array}$ & $\begin{array}{c}\text { Average length of } \\
\text { stay for inpatient } \\
\text { (Min) }\end{array}$ & $\begin{array}{c}\text { Improvement in } \\
\text { average length of } \\
\text { stay for inpatient } \\
\%\end{array}$ \\
\hline 3 current system & 59.6 & - & 603.6 & - \\
\hline 4 & 59 & $1 \%+$ & 600.1 & $0.58 \%+$ \\
\hline
\end{tabular}

One of the key resources in ED is GP. In the current system two GPs visit patients in per shift. By adding 1 GP, the rate of this resource is reduced 26\% and it can affect outpatient length of stay directly. Outpatient arrival to ED until visiting a GP takes 12 minutes. While by adding $1 \mathrm{GP}$ it can be 7 minutes and this has led to better patient flow for continuing treatment and also has 1.1\% improvement in inpatient length of stay. In the following we notice to combined scenarios such as adding two beds and one GP or adding three beds and one GP. Table 6 shows summarize of different scenarios.

Table 6: Simulation result under different scenarios

\begin{tabular}{|l|l|c|c|c|c|c|c|c|c|}
\hline \multicolumn{2}{|l|}{ Key performance } & $\begin{array}{c}\text { Current } \\
\text { system }\end{array}$ & $\begin{array}{c}\text { Adding } \\
\text { one } \\
\text { bed }\end{array}$ & $\begin{array}{c}\text { Adding } \\
\text { two } \\
\text { beds }\end{array}$ & $\begin{array}{c}\text { Adding } \\
\text { three } \\
\text { beds }\end{array}$ & $\begin{array}{c}\text { Adding } \\
\text { one } \\
\text { Nurse }\end{array}$ & $\begin{array}{c}\text { Adding } \\
\text { one } \\
\text { GP }\end{array}$ & $\begin{array}{c}\text { Adding } \\
\text { two } \\
\text { beds } \\
\text { and one } \\
\text { GP }\end{array}$ & $\begin{array}{c}\text { Adding } \\
\text { three } \\
\text { beds and } \\
\text { one GP }\end{array}$ \\
\hline \multirow{2}{*}{$\begin{array}{l}\text { Resource } \\
\text { utilization } \\
(\%)\end{array}$} & Bed & 0.86 & 0.80 & 0.75 & 0.71 & 0.86 & 0.86 & 0.75 & 0.71 \\
\cline { 2 - 10 } & Nurse & 0.52 & 0.52 & 0.52 & 0.52 & 0.49 & 0.52 & 0.52 & 0.52 \\
\cline { 2 - 10 } & \multirow{2}{*}{ GP } & 0.74 & 0.74 & 0.74 & 0.74 & 0.74 & 0.48 & 0.48 & 0.48 \\
& & & - & - & - & - & $35.1 \%+$ & $35.1 \%+$ & $35.1 \%+$ \\
\hline
\end{tabular}


Using simulation to improve hospital resource management

\begin{tabular}{|c|c|c|c|c|c|c|c|c|c|}
\hline \multirow{2}{*}{$\begin{array}{l}\text { Average } \\
\text { wanting } \\
\text { time(min) }\end{array}$} & Visit GP & 4.91 & $\begin{array}{r}4.92 \\
0.2 \%- \\
\end{array}$ & $\begin{array}{c}5.1 \\
3.8 \%- \\
\end{array}$ & $\begin{array}{c}4.87 \\
0.81 \%+\end{array}$ & $\begin{array}{r}4.98 \\
1.4 \%- \\
\end{array}$ & $\begin{array}{c}0.89 \\
81.8 \%+ \\
\end{array}$ & $\begin{array}{c}0.89 \\
81.8 \%+\end{array}$ & $\begin{array}{c}0.88 \\
82 \%+\end{array}$ \\
\hline & $\begin{array}{l}\text { Taking } \\
\text { bed }\end{array}$ & 59.6 & $\begin{array}{l}31.63 \\
46 \%+\end{array}$ & $\begin{array}{l}15.22 \\
74 \%+\end{array}$ & $\begin{array}{c}8.35 \\
85 \%+\end{array}$ & $\begin{array}{c}59 \\
1 \%+\end{array}$ & $\begin{array}{l}58.1 \\
2 \%+\end{array}$ & $\begin{array}{c}15.4 \\
47 \%+\end{array}$ & $\begin{array}{c}8.31 \\
86 \%+\end{array}$ \\
\hline \multirow{2}{*}{$\begin{array}{l}\text { Average } \\
\text { length of } \\
\text { stay(min) }\end{array}$} & Outpatient & 78.53 & $\begin{array}{c}78.50 \\
0.03 \%+\end{array}$ & $\begin{array}{c}78.86 \\
0.42 \%-\end{array}$ & $\begin{array}{c}77.82 \\
0.9 \%+\end{array}$ & $\begin{array}{c}78.63 \\
0.12 \%-\end{array}$ & $\begin{array}{c}71.81 \\
8.5 \%+\end{array}$ & $\begin{array}{c}71.66 \\
8.7 \%+\end{array}$ & $\begin{array}{c}71.89 \\
8.4 \%+\end{array}$ \\
\hline & Inpatient & 603.6 & $\begin{array}{c}576.5 \\
4.4 \%+\end{array}$ & $\begin{array}{l}564.2 \\
6.5 \%+\end{array}$ & $\begin{array}{c}558.1 \\
7.5 \%+\end{array}$ & $\begin{array}{c}600.1 \\
0.58 \%+\end{array}$ & $\begin{array}{l}602.9 \\
1.1 \%+\end{array}$ & $\begin{array}{c}559 \\
7.3 \%+\end{array}$ & $\begin{array}{c}553.8 \\
8.2 \%+\end{array}$ \\
\hline
\end{tabular}

For outpatient adding on GP has $81.8 \%$ reduction in waiting time and thus $8.5 \%$ improvement in length of stay. For taking bed Patients should wait 59.6 minutes that $s$ too long and requires serious attention. The result show adding one GP and 3 beds have most improvement in both average wanting time and average length of stay and can be selected as best scenarios.

\section{Conclusion}

Patient satisfaction improvement is very important issue in the health sector. This aim can be achieved in various ways, such as reducing queues, costs, improve service quality. The current study focused on ED and resource utilization, patient's average wanting time and average length of stay. We present different scenarios and adding one GP and 3 beds is best scenarios in this part.

Using simulation considered as an effective tool for improvement in the health sector in many countries but in Iran has less attention to it. Unwillingness and lack of cooperation from authorities in the health sector is one of the main limitations of this study .Limitations in data collection and tracking patients at different times was another problem. But we hope that this paper can be the beginning of a new approach to application simulation and its potential benefits in the health sector in this country.

\section{Literature}

- Ahmad, N., Abdul Ghani, N., Abdulbasah Kamil, A., Mat Tahar, R., \& Howe Teo, A. (2012). Evaluating Emergency Department Resource Capacity Using Simulation. Modern Applied Science, 6(11).

- Ahmed, M., \& Alkhamis, T. (2009). Simulation optimization for an emergency department healthcare unit in Kuwait. European Journal of Operational Research, 198, pp. 936-942.

- Alkaabi, R., El Halim, A., \& Mahmoud, S. (2006). Improving resource allocation efficiency in health care delivery systems. Ieee ccece/ccgei. 
- Berge Holm, L., \& Dahl, F. (2010). Simulating the influence of a 45\% increase in patient volume on the emergency department of akershus university hospital. Proceedings of the 2010 Winter Simulation Conference.

- Brailsford, S., \& Vissers, J. (2011). OR in healthcare: A European perspective. European Journal of Operational Research, 212, pp. 223-234.

- Cochran, J., \& Broyles, J. (2010). Developing nonlinear queueing regressions to increase emergency department patient safety: Approximating reneging with balking. Computers and Industrial Engineering, 59, pp. 378-386.

- Faezipour, M., \& Ferreira, S. (2013). A system dynamics perspective of patient satisfaction in healthcare. Procedia Computer Science, 16, pp. 148 - 156.

- Ferreira, J., Gomes, C., \& Yasin, M. (2011). Improving patients' satisfaction through more effective utilization of operating rooms resources An informational-based perspective. Clinical Governance: An International Journal, 16(4), pp. 291-307.

- Ferreira, J., Gomes, C., \& Yasin, M. (2011). Improving patients'satisfaction through more effective utilization of operating rooms resources An informational-based perspective. Clinical Governance: An International Journal 16(4), pp. 291-307

- Khandekar, S., Mari, J., \& Wang, S. (2007). Implementation of Structural Changes to the Care Process in the Emergency Department using Discrete Event Simulation. Proceedings of the 2007 Industrial Engineering Research Conference.

- $\quad$ Ng, C.-J., Hsu, K.-H., Kuan, J.-T., Chiu, T.-F., Chen, W.-K., Lin, H.-J., et al. (2010). Comparison Between Canadian Triage and Acuity Scale and Taiwan Triage System in Emergency Departments. Journal of the Formosan Medical Association, 109(11).

- Sadjadi, S., Soltani, R., Izadkhah, M., Saberian, F., \& Darayi, M. (2011). A new nonlinear stochastic staff scheduling model. Scientia Iranica E, 18(3), pp. 699-710.

- Weng, S.-J., Cheng, B.-C., Ting Kwong, S., Wang, L.-M., \& Chang, C.-Y. (2011). Simulation optimization for emergency department resources allocation. Proceedings of the 2011 Winter Simulation Conference.

- Withanachchi, N., Uchida, Y., Nanayakkara, S., Samaranayake, D., \& Okitsu, A. (2007). Resource allocation in public hospitals: Is it effective? Health Policy 80, pp. 308-313.

- Xu, M., Wong, T., \& Chin, K. (2013). Modeling daily patient arrivals at Emergency Department and quantifying the relative importance of contributing variables using artificial neural network. Decision Support Systems, 54, pp. 1488-1498.

Paper received: May $15^{\text {th }}, 2014$

Approved for publication: June $1^{\text {st }}, 2014$
Rad primljen: 15. maj 2014. Odobren za štampu: 1. jun 2014. 
Khodakaram Salimifard,

Univerzitet u Persijskom zalivu, Iran

Dariuosh Moha mmadi Zanjirani,

Univerzitet Esfahan, Iran

Leyla Keshtkar,

Univerzitet u Persijskom zalivu, Iran

\section{UPOTREBA SIMULACIJE S CILJEM POBOLJŠANJA UPRAVLJANJA LJUDSKIM RESURSIMA U BOLNICAMA}

\section{S a ž e t a k}

Ambulanta hitne medicinske pomoći je jedan od ključnih delova zdravstvene zaštite. Povećana potražnja za urgentnom negom, gužve i ograničeni resursi uzrok su dugih čekanja pacijenata $u$ ambulantama hitne medicinske pomoći. S druge strane, pacijenti ne bi trebalo predugo da se zadržavaju u njima. Dugo čekanje pacijenata dovodi do zagušenja i nereda. Ova studija teži smanjenju čekanja i dužine boravka pacijenata u ambulanti za hitne slučajeve.

Idealno rešenje, uvidom u rezultate simulacije, su dodatna tri ležaja i jedan doktor medicine što poboljšava korišćenje ležaja za 17,4\% i 34,1\% kvalitet stručne medicinske pomoći. Isto tako poboljšava prosek čekanja na doktora i hospitalizaciju za $82 \%$ odnosno $86 \%$, pritom umanjujući dužinu boravka za $8 \%$.

Ključne reči: ambulanta hitne pomoći, dužina boravka, resursna alokacija, simulacija 
